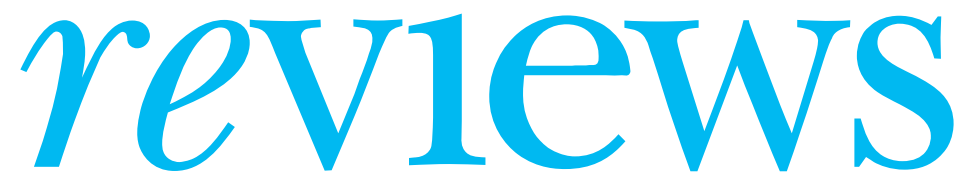

BOOKS • CD ROMS • ART •WEBSITES $\bullet$ MEDIA $\bullet$ PERSONAL VIEWS $\bullet$ SOUNDINGS

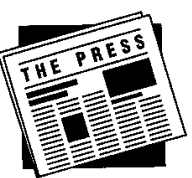

\section{A different picture of Africa}

$\mathrm{I}$ has to be one of the more bizarre ventures-publishing a glamorous women's magazine in the world's 14th poorest country. Last November that's exactly what happened with the launch of Beauty Zambia.

Zambia is home to 10 million peoplemany with zero income, a lack of clean water, and periods of hunger. Poverty is real, yet every month Beauty Zambia is a glossy riot of colour, fashion, and features. How can this be?

Even in a country like Zambia there are new cultural identities forming. Stereotypes of Africa include poverty, war, famine, disease, or exotic wildlife-not perhaps a place of fashion models, professional workers, nightclubs, fancy restaurants, cellphones, and rush hour streets at near gridlock with imported Japanese cars.

This highlife is experienced by a lucky few, in contrast to others on lower incomes with greater social problems. Publishers in Western countries rarely consider the tensions such diverse audiences create.

Criticisms of women's media include that it keeps women in subordinate positions, provides incorrect or inadequate health information, privileges appearance over achievements, and reduces women's lives to sex and relationships. At a time when women's magazines rarely include interviews with non-celebrity older women, Beauty Zambia has featured interviews with nurses, teachers, and even police chief superintendent Brenda Muntemba.

Many Western magazines seem afraid to cover gender issues. Zambian society is still very male centred. To illustrate this, the magazine's most recent monthly vox pop revealed some startling comments from conservative male interviewees on women's dress, including such gems as a request for miniskirts to fall below the knee, and for a government devised dress code.

Our aim with the magazine is to support Zambian women to enjoy life and build confidence through articles on hobbies and sports (reading, swimming, weight training), and education and career advice (hotel management, workplace discrimination, presentation skills). Readers are involved through "word on the street" discussions of topical issues, by texting in their questions or comments, and reader essay competitions. Not that this puts men off-a large proportion of our readers are male.

By being ruthlessly commercial and relying on advertising, the magazine plans to continue publishing long term, where other donor driven publications invariably fall by the wayside once funding expires. The magazine has a monthly print run of 2000 copies, although each copy is read by many more people, lifting readership figures to an estimated 15000 to 20000 copies a month. At 7500 kwacha (slightly less than a pound) it is a quarter of the price of the imported glossies.

In the past year the magazine has run stories on menstruation, breast and cervical cancer, HIV, smoking cessation, malaria dangers during pregnancy, stress management, and dental care, all tailored to an African audience. Every health feature is informed by and links to current evidence, something most Western magazines miss.

\section{We have deliberately not taken a preaching role on HIV/AIDS or other \\ lifestyle issues}

All these ingredients add up to a huge dichotomy being grappled with by many of our readers-the allure of the modern versus the pull of tradition. It makes for baffling times, and is played out every month in the magazine's problem page.

Some problems-jealousy, relationship dissatisfaction, or sexual concerns-are similar the world over. Some are Zambianspecific-coping with the hunger season, long distance relationships, or extended families. The traditional Western practice of advising readers to make decisions to suit themselves, to pamper themselves, or to seek out health or therapy resources may be impractical or incomprehensible. Even those problems that seem to be shared across countries still need to be answered in a way that respects cultural issues rather than imposes Western values upon them.

HIV/AIDS is a prime example. According to 2003 estimates, $16 \%$ of adults in Zambia are HIV positive. Prevalence rates vary between urban and rural areas. Donors have pumped tens of millions of pounds into the country to try to tackle the

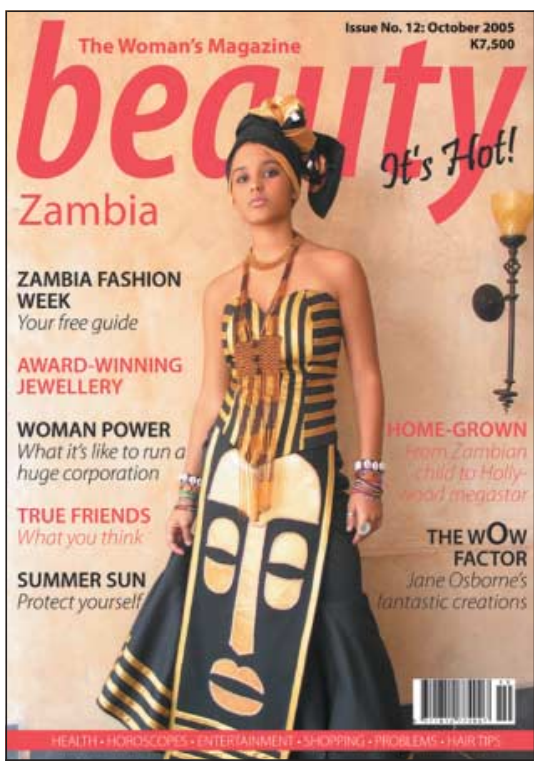

Showing a glamorous and hopeful side to life

epidemic, both by prevention messages and care of those infected. Yet on the ground, especially in poorer households and rural areas, little real impact seems to have been made.

At Beauty Zambia, while we respect the work of educators and volunteers, we often feel that experts are trying too hard to impose Western approaches without really understanding the African psyche and way of life. How can you tell someone not to have unsafe sex because they could become infected with HIV and die in five or ten years' time? They may reason that they are more likely to die from malaria or be bitten by a snake well before then.

Learning from these problems, we have deliberately not taken a preaching role on HIV/AIDS or other lifestyle issues. At the request of our readers, we have specifically avoided being dragged into "workshopspeak" and relentless anti-AIDS messages.

We cannot ignore the realities touching our readers' lives. Every month we run an accurate health story. But we also aim to paint an alternative aspect, profiling role models, showing a glamorous, fun, and hopeful side to life- $-\mathrm{a}$ different picture of Africa.

Gillian Baker editor, Beauty Zambia beauty@langmead.com

Petra Boynton lecturer in international health research, London, and agony aunt, Beauty Zambia p.boynton@pcps.ucl.ac.uk 


\section{Africa Live}

Directed by Mick Czáky

To be broadcast throughout Africa DVD release date: September 2005 www.africalive-festival.com

Rating: $\star \star \star \star$

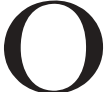

$\mathrm{n}$ a stage with billowing nets and giant "mosquitoes"-dancers dressed in costumes designed by Oumou Sy-Nigeria's Seun Kuti mesmerised a crowd of 50000 with his "Mosquito Song." This slightly surreal public health message is one of the highlights from a concert in Dakar on 12-13 March this year that was organised by Senegalese Grammy winner Youssou N'Dour. More than 150 of Africa's top musicians entertained concertgoers-and warned of malaria's dangers. The concert, backed by the Roll Back Malaria Partnership, features performances from former Rwandan refugee (and now, heartthrob) Corneille, Cameroon's Manu Dibango, Malian legend Salif Keita, Touareg group Tinariwen, and Congo's Awilo Longomba.

Mick Czáky, director of Africa Live, first had the idea for an anti-malaria concert in 2003 when he met with Senegal's President
Wade and Youssou N'Dour. "I'm terribly keen on African music. When I first thought of the Africa Live project, I had only two rea thoughts. One was that it should be a positive way of presenting Africa that wasn't negative. I thought it would be fun to celebrate Africa with a spectacular concert with worldwide distribution," he said.

The event was filmed by the BBC as a documentary and has been donated by the film's producers to pan-African broadcasters, who will be able to show it free of charge The decision to make the film free for broadcasters was simple. "Education, education, education," said Mr Czáky. "It's the best way of reaching the middle classes, who may already have their nets but need to think of their employees and fellow citizens."

Backed by the Grand Orchestre du Caire, Youssou N'Dour told fans to stop the disease, which he calls "the tsunami that happens in Africa every day, where two million children die from something we can prevent together." Similarly, Orchestra Baobab chanted "Down with Malaria!" with the crowd. Ironically, there are shots of open sewers outside the concert venue as a reminder that malaria lurks everywhere.

Africa Live is also available on DVD to help educate Westerners who are unaware of Africa's malaria epidemic. Malaria was eradicated from southern Europe and the United States in the 1960s. It has reappeared with a vengeance in Africa thanks to the conflicts and disasters of the 1980s and 1990s, when control efforts and healthcare systems collapsed.

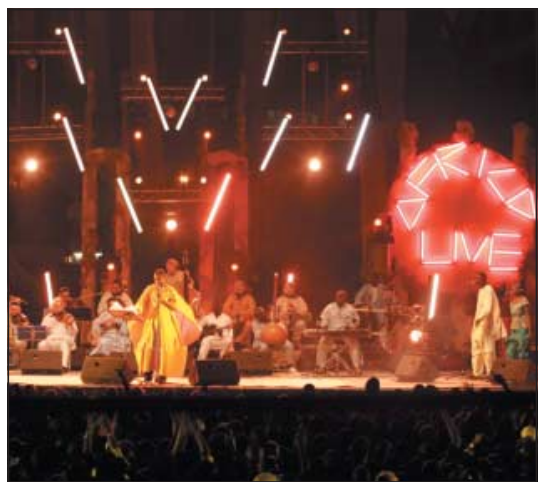

Celebrating Africa: Youssou N'Dour and the Grand Orchestre du Caire

The concert's message seems to be spreading in Africa, and Kevin Starace of the UN Development Programme feels the DVD will be an important tool in reaching the West. Music, said Mr Starace, is universally appealing and a useful "entertainment mechanism" for promoting awareness. "We've reached a lot of people on the radio [in Africa] but there's also the other audience in the Western world. Malaria is often overshadowed by uncurable diseases like AIDS and SARS," he said.

A visual and musical feast, Africa Live finishes with a rendition of the spine tingling Swahili song "Malaika" by Angelique Kidjo, which Mr Czáky said had generated "tons of mail."

Leslie Lee freelance journalist, London lesliealee@earthlink.net

\section{As They See It: The Development of the African AIDS Discourse} Raymond Downing

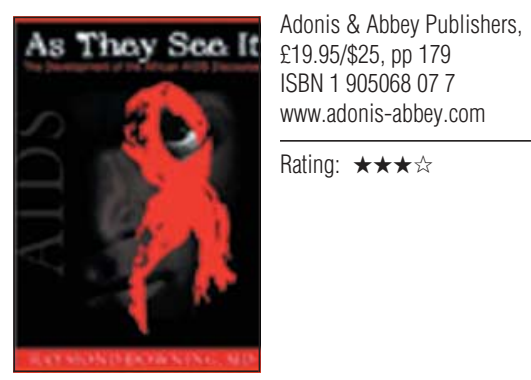

$\mathrm{T}$ he subject of this book is what Africans think and say about HIV and AIDS. While author Raymond Downing, a pro-African Westerner, appears to have written it for Westerners, it will interest both Africans and non-Africans with an interest in fighting the disease.

African voices have historically been ignored in the discourse around AIDS,

Items reviewed are rated on a 4 star scale (4=excellent) which is what has prompted the author to write this book. It perhaps would have been preferable if an African had written it, but a lack of resources are a major hindrance to an African writer undertaking such a project.

As They See It looks at AIDS from multiple African perspectives, and provides a thorough overview of the African experience, covering various countries with different socioeconomic status, different HIV prevalence, and different cultural viewpoints.

One of the topics covered is the debate over the origin of HIV. The Western press reported that the virus originated from Africa, but some Africans question why it therefore took so long to witness the first clinical AIDS case in North America in the early 1980s. Such a discrepancy confuses African and makes them feel judged.

Moreover, Downing indicates how HIV/ AIDS statistics from Africa may be unreliable, by baseline measures or methods of statistical analysis. To illustrate this he describes how his wife received a false positive HIV diagnosis with enzyme linked immunosorbent assay (ELISA), the test mostly used in Africa. The diagnosis was later proved negative by Western blot method. Downing explains how poverty leads many Africans to live with false positives, as they cannot afford Western blot confirmation. This can destroy someone's future, as happened with one of the book's case studies, Frank, who lost a scholarship, before learning after many years that he was living with false positive HIV results.

The book also describes how South African president Thabo Mbeki, by associating HIV and poverty, received a negative reaction from many stakeholders in Western countries. But through failing to listen to Mbeki's point and by ignoring him, appropriate ways of fighting AIDS in Africa, other than the use of antiretroviral drugs, may have been lost.

Downing clearly illustrates how culturesuch as a belief in witchcraft-is a vital component to consider when addressing HIV/ AIDS. I have worked as a youth activist in Tanzania for the past five years, addressing issues on sexual health and HIV/AIDS prevention. From this, I can see how young people, for example, have their own "new culture" that is neither traditional African nor Western. In order to deal with HIV awareness, people need to understand these cultural differences and respond in consultation with local people.

Dunstan Raphael Bishanga final year medical student, Dar es Salaam, Tanzania

dbishanga@yahoo.com 


\section{Africa does not need aid, but the opportunity for fair trade}

$\mathrm{A}^{\mathrm{n}}$ frica has been in the international news mostly for the wrong reasons and notably in the recent past for famine, the HIV/AIDS pandemic, civil wars, and increasing poverty. It is common knowledge that the continent is rich in natural resources, but its people continue to languish in absolute poverty. Some factors that could explain this are corruption, unequal distribution of wealth, poor planning, lack of respect for the rule of law, manipulation by developed countries, civil wars, illiteracy, and the current HIV/AIDS pandemic. All these factors have worked in synergy to reverse the little gain the continent had made in the early 1970s.

Most African countries have welcomed recent debate (such as that at the G8 summit in Gleneagles, Scotland, in July of this year) on increased aid and debt relief to impoverished nations by the world's leading industrialised countries. It is important to note, however, that such pledges have been made before, and yet poverty levels have increased. Rich nations, and G8 nations in particular, are notorious for giving impoverished countries postdated cheques of increased ODA (official development assistance) and better terms of trade and debt relief that are shamelessly dishonoured.

The World Bank and the International Monetary Fund (IMF) have been pushing poor African governments with aid conditions that are of no particular benefit to the people of Africa. A case in point is privatisation of organisations that provide essential services to a country's citizens-for example, telecommunications, power, water, roads, railways, banks, and ports. All these lucrative business are now in the control of powerful multinationals reaping huge profits and sending all the funds to their home countries, leaving Africa worse off than before. If the profits made by these multinationals are not ploughed back into the local economy, then this will be the worst trick that the World Bank and IMF have played on Africa and impoverished countries in general.

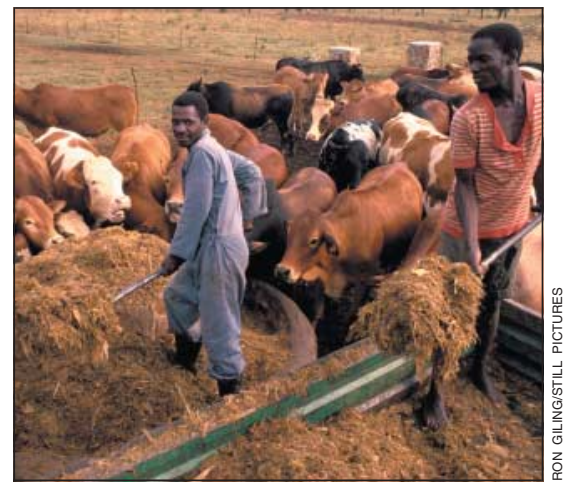

Most farmers are forced to sell at a loss
On one hand there is pressure on a government to reduce its workforce, rendering millions of family breadwinners jobless; on the other hand we see a continuous increase of expatriates purporting to give technical support even where there are highly qualified locals for the job. High unemployment and low pay have led masses of qualified staff to leave Africa and move to the developed countries in search for work, sparking the current debate about the "brain drain." Unless unemployment is addressed, the "brain drain" will continue.

In the current climate, Africa is not expected to meet the poverty reduction goal by 2015 . If there is to be any achievement we urgently need to shift policies, with deliberate focus on capacity building, improved quality of aid, and full and unconditional cancellation of debt owed by all impoverished countries. We need to reform the World Trade Organization to give poor nations full and effective representation at policy level and ownership of development policies that fully protect human rights.

An early end to agricultural export and farm subsidies in developed countries is a necessary and essential part of anti-poverty efforts. The import of cheap food to poor countries during the peak of the harvest season has a negative impact on the economy and promptly kills local agriculture, as peasant farmers do not get a market for their produce. Most farmers do not have the capacity to preserve and store the produce safely, forcing them to sell at a loss. Where farmers have attempted to store the produce, there have been disastrous results, as evidenced by a case in Kenya earlier this year when many lives were lost to aflatoxin poisoning resulting from poorly stored grains.

Last month about 200 heads of state gathered at the United Nations headquarters in New York to review achievements made, if any, since the millennium summit of 2000 that gave us the much celebrated millennium development goals. Concerns raised during the meeting are closely linked to those expressed in the recent past by the Global Call to Action against Poverty (GCAP), the worldwide coalition that seeks to prick the conscience of the global citizenry to address socioeconomic injustices with a view to making poverty history. As the debates go on, millions continue to die from hunger, poverty, and disease.

All these meetings and slogans will never achieve the desired goal as long as the most impoverished countries have no major input into the process. As the saying goes, beggars can't be choosers. But what African leaders should realise is that poverty in Africa needs to be addressed from within the continent-no single country has ever developed by depending on aid from its former masters. Africa can develop with the resources in its possession, so long as there is no external interference and there is fair trade and democracy. The continent needs to take charge of its destiny or it will never liberate itself from this unfortunate situation.

\section{Inwani Malweyi emergency medical coordinator, Merlin Kenya \\ kenya.emergency.medco@merlin-eastafrica.org}

The views expressed are the writer's own, and do not represent those of Merlin.

\section{Hit parade bmj com}

These articles scored the most hits on the BMSs website in their first week of publication

\section{AUGUST}

1 Editorial: Delayed prescribing of antibiotics for upper respiratory tract infection BMJ 2005;331:301-2 4626 hits

2 Editorial: Combing and combating head lice BMJ 2005;331:362-3 4339 hits

3 Editor's choice: Let's call it cardiac impairment BMJ 2005;331 (20 August) 4198 hits

4 News: Breast cancer screening does not save lives, study shows BMJ 2005;331:309 4086 hits

5 Education and debate: Hormone replacement therapy and breast cancer: estimate of risk BMJ 2005;331:347-9 3797 hits

6 Clinical review: Evidence based case report: Should a patient with primary intracerebral haemorrhage receive antiplatelet or anticoagulant therapy? BMJ 2005;331:439-42 3758 hits

7 Personal view: The finger, the foot, my bone cancer BMJ 2005;331:463

3735 hits

8 Paper: Cholinesterase inhibitors for patients with Alzheimer's disease: systematic review of randomised clinical trials BMJ 2005;331:321-7 3629 hits

9 Paper: Role of mobile phones in motor vehicle crashes resulting in hospital attendance: a case crossover study BMJ 2005;331:428 3597 hits

10 10-minute consultation: Anaphylaxis BMJ 2005;331:330 3586 hits

All articles cited are full text versions. 


\section{Western and traditional African medicine- working together on AIDS}

A dangerous gap exists rural areas. Perhaps to man-
I

n southern Africa, antiretroviral drugs are a late entrant in an already vibrant market for AIDS treatments. Traditional medicine does not treat HIV infection as such but does provide many supportive therapies. Whatever its credibility in the eyes of university trained doctors, the "neotraditional" management of AIDS has gained a space in the market. Recognition of this economic reality could be important for the success of antiretroviral treatment.

In South Africa's central Free State province $30 \%$ of householders said they would recommend a traditional healer to manage AIDS, and only half had even heard of antiretrovirals. The low uptake of free antiretrovirals in countries such as Botswana should be another clue that the treatment is not an easy fix. Among other problems, people need to know and to accept their HIV status before they can receive treatment. The conditions for disclosure are not good in southern Africa, where the fear of stigmatisation and economic loss is widespread. between what university trained doctors or nurses know about antiretroviral treatment and the way ordinary people make sense of the treatment, especially in
I see modern

approaches to AIDS reaching an invisible limit as they confront the traditional approaches
Disrespect and lack of understanding are shown on both sides. University trained doctors are often patronising and intolerant of traditional medicine, and many traditional healers are no more tolerant of Western solutions. Mutual mistrust could be reduced by a two way translation of knowledge. In modern medicine, it makes no sense to share a course of antiretroviral treatment among family members or to stop taking antibiotics after some improvement is shown. In traditional medicine, by the same token, it makes no sense to consider the pharmaceutical effect of herbs or roots outside their spiritual context.

The standoff between modern and traditional approaches focuses the discourse on AIDS on tertiary prevention (minimising the worst consequences for people who are already affected). Yet even this can be a negative contribution. Restructured budgets to buy expensive antiretrovirals and the vertical management of treatment programmes can weaken primary care services.

We might ask about other aspects of tertiary prevention, such as medical attention other than antiretroviral treatment, care at home, care of orphans, or food security-or how investment in tertiary preage expectations better,

health services have communicated little to the general public about the specifics of antiretroviral treatment. Most people get their information from the mass media, and their understanding is not helped by mixed messages from senior politicians. The resulting misconceptions in the community affect adherence to the treatment (BMJ 2004;328:242-2). Health workers' misunderstanding of and disrespect for views in the community do not help. Under-use or even misuse of antiretroviral treatment can discredit its importance (BMJ 2004;328:280-2).

This gap in knowledge serves some interests. Leakage of antiretrovirals from the periphery of the health system, where accountability is weakest, is a profitable new economy. AIDS is too big a catastrophe, and its effect on health services too profound, for this situation to be allowed to continue. Might there be a place for a new solution that combines traditional and modern approaches?

In southern Africa we can learn from countries in other African regions about mutual respect between modern and traditional medicine. One small Ugandan initiative, for example, placed a traditional healer next to a modern doctor to provide consultations for patients with HIV or AIDS (www.thebody.com/bp/oct98/uganda.html).
Neil Andersson executive director, CIET Trust, Saxonwold, South Africa neil@ciet.org

\section{SOUNDINGS}

\section{Out of Africa}

Flying across eastern Africa most Mondays for almost 30 years, the surgeon-pilot observed how population growth and environmental destruction went hand in hand, and how the increase in energy use-local and

global-changed geography.

He monitored how the glaciers on

Mount Kenya and the Ruwenzoris were receding and how the snows of Kilimanjaro were melting. He saw the forests disappearing, the wetlands vanishing, and the rivers either drying up or in raging flood, carrying the fertile red soil out into the sea, and he noticed the steady advance of the desert.

He saw huts, houses, villages everywhere, tracks, roads, and highways, and he flew over huge tracts of land assigned to monoculture: tea, coffee, sugar, wheat, maize, pineapples, and flowers, most destined for export. $\mathrm{He}$ flew over struggling subsistence farms, getting increasingly smaller.

Landing at the hospital early in the morning he would be confronted with multitudes of sick people lining up for surgery. He had to decide whether to treat the sickest or the ones with the best prognosis-usually the utilitarian argument won.

Over the years the epidemiology presenting to him changed. There were the old diseases, mostly infectious; then came the trauma epidemic, first road crashes and then violence; next were the cosmopolitan cancers; and recently, with Western lifestyles, and sugar, sodas, salt, refined fats, and the lack of exercise, the degenerative diseases.

The population pyramid also changed. More children, children everywhere, wonderful, bright, joyous children, but, in ecological terms, acting like locusts nevertheless ... Eventually AIDS began to nibble at the pyramid: the children would be attended by the grandparents. But the surgeon-pilot was not there to philosophise, he was there to give advice, to teach, to mend ... to radiate hope.

On his way home in the evening, when the cumulus clouds in the west became golden and then purple, the lakes silver, and the silhouettes of the mountains cast variegated shadows over the land, the surgeon-pilot's heart was filled with elation, while his mind was preoccupied with the state of Africa, the continent overwhelmed by rapid unimaginable stresses caused by environmental dislocation.

Imre Loefler editor, Nairobi Hospital Proceedings, Kenya technological change and heading for 